\section{Prescribing errors in a Brazilian neonatal intensive care unit}

\author{
Erros de prescrição em uma unidade de terapia \\ intensiva neonatal brasileira
}

\section{Errores de prescripción en una unidad de terapia intensiva neonatal brasileña}

\author{
1 Universidade Federal de \\ Uberlândia, Uberlândia, \\ Brasil. \\ Correspondence \\ V. O. S. Abdallah \\ Universidade Federal de \\ Uberlândia. \\ Rua Acre 855, Uberlândia \\ MG 38405-319, Brasil. \\ vosabdallah@hotmail.com
}

\begin{abstract}
Pediatric patients, especially those admitted to the neonatal intensive care unit (ICU), are highly vulnerable to medication errors. This study aimed to measure the prescription error rate in a university hospital neonatal ICU and to identify susceptible patients, types of errors, and the medicines involved. The variables related to medicines prescribed were compared to the Neofax prescription protocol. The study enrolled 150 newborns and analyzed 489 prescription order forms, with 1,491 medication items, corresponding to 46 drugs. Prescription error rate was $43.5 \%$. Errors were found in dosage, intervals, diluents, and infusion time, distributed across 7 therapeutic classes. Errors were more frequent in preterm newborns. Diluent and dosing were the most frequent sources of errors. The therapeutic classes most involved in errors were antimicrobial agents and drugs that act on the nervous and cardiovascular systems.
\end{abstract}

Inappropriate Prescribing; Premature Infant; Newborn Infant; Neonatal Intensive Care Units

\author{
Ana Paula Cezar Machado 1 \\ Catharina Somerlate Franco Tomich 1 \\ Simone Franco Osme 1 \\ Daniela Marques de Lima Mota Ferreira 1 \\ Maria Angélica Oliveira Mendonça 1 \\ Rogério Melo Costa Pinto 1 \\ Nilson Penha-Silva 1 \\ Vânia Olivetti Steffen Abdallah 1
}

\section{Resumo}

Pacientes pediátricos, principalmente internados em unidades de terapia intensiva (UTI) neonatal, são altamente vulneráveis aos erros de medicação. O objetivo deste trabalho foi conhecer a frequência dos erros de prescrição em uma UTI neonatal de um hospital universitário, bem como os pacientes susceptiveis, os tipos de erros e os medicamentos envolvidos. As variáveis prescritas relacionadas aos medicamentos foram comparadas com a base utilizada como referência para a prescrição na unidade (Neofax). Participaram do estudo 150 recém-nascidos. Foram analisadas 489 prescrições, 1.491 itens de medicamentos, correspondendo a 46 fármacos. A taxa de erros de prescrição foi de 43,5\%. Foram encontrados erros de dose, intervalo, diluente e tempo de infusão, distribuídos em sete classes terapêuticas. A ocorrência de erros foi maior em recém-nascidos pré-termos. Os erros de diluente e de dose foram os mais frequentes. As classes de medicamentos mais envolvidas nos erros foram os anti-infecciosos e aqueles que atuam nos sistemas nervoso e cardiovascular.

Prescrição Inadequada; Prematuro; Recém-Nascido; Unidades de Terapia Intensiva Neonatal 


\section{Introduction}

Pediatric patients, especially those admitted to neonatal intensive care units (ICU), are highly vulnerable to medication errors $1,2,3$. The immaturity of organs causes difficulties for neonates, especially the very premature, to adapt to extra uterine life, because they often have multiple morbidities and need complex and intensive medical care. This exposes them to a high number of prescriptions, and a greater risk of adverse reactions 4 .

The repertoire of prescribed drugs in the neonatal ICU is relatively limited compared to the ICU, whether pediatric or adult, however the process of prescribing, dispensing and administrating drugs is much more complex ${ }^{2}$. Although advances in clinical trials for medications in pediatrics have increased considerably in recent years, the use of off label drugs remains a major public health problem for newborns, particularly for preterm newborns and children with rare diseases, which makes the use of off label drugs a common and necessary practice when there is no pharmacological alternative ${ }^{5}$. The necessity of using weight and body surface in the calculation of doses and pharmacological factors such as variation in the rate of absorption, metabolism and excretion of drugs, make the drug therapy more prone to errors in this population 1,2,6. In addition, children and especially newborns have lower internal reserves compared to adults, and therefore are less able to mitigate errors 1,2,7.

Studies in developed countries have shown that most errors occur during the prescription $1,7,8,9$. One of the challenges of the prescription process is that most drugs are available only in formulations and concentrations for adults and must be diluted or modified for use in children, requiring a larger number of calculations and thereby increasing the likelihood of errors 10,11. In addition, some medications used in the neonatal ICU have complex doses, with very strict intervals and a narrow therapeutic index 12 , and if they are not properly prescribed can cause severe injury or even death 13 .

Although the errors involve people, human failures are only a small part of the problem. According to Reason 14, human beings are fallible and errors are to be expected even in the best organizations. Thus, in the hospital environment errors should be treated as deviations from the drug use process ${ }^{6}$ and strategies for their prevention are necessary.

Considering the peculiarities of newborns and their vulnerability to medication errors, this study aimed to assess the frequencies of prescribing errors in a neonatal ICU, as well as the characteristics of susceptible patients, the types of errors, and the drugs involved.

\section{Methods}

This single-centered retrospective study was previously approved by the Ethics Research Committee of the Federal University of Uberlândia, under protocol 321/11. Data of newborns admitted to the neonatal ICU of a federal university hospital in the Triângulo Mineiro region of the state of Minas Gerais, Brazil, from January 2011 to September 2011 were collected.

\section{Population}

The study population consisted of 151 patients. The study included newborns with a minimum stay of 24 hours in the neonatal ICU and who have had at least one prescribed drug. In cases of readmission, the newborn was recorded as a new patient. Newborns were classified according to gestational age (GA) in preterms (GA $<37$ weeks) and terms (GA $\geq 37$ weeks) 15 .

\section{Sample}

The data was collected from prescription order forms containing at least one drug prescribed for infants who remained at least 24 hours in the unit. Since this is a retrospective study, the period of January to September 2011 was chosen for the data collection. Upon completion of the collection, all data collected in the period was analyzed.

\section{Place of study}

The study was conducted in the neonatal ICU of a federal teaching hospital considered as reference in the region. Prescriptions were manually written every 24 hours and reviewed by the medical staff as needed. The medical and nursing teams have defined protocols for patient care, including the use of diluents and infusion rate for some medications. All medications are prepared by the nursing staff. The hospital pharmacy service of this hospital does not have a unit dose distribution system. The unit has no clinical pharmacist, and when necessary, information is requested from the clinical hospital pharmacy service.

\section{Data collection}

Data of prescribed drugs were collected from prescription order forms at four different times during the hospitalization: the first 24 hours, the 
3rd and 5th days of hospitalization and at discharge from the unit. The early neonatal period was chosen because it is considered a critical period of stay in the neonatal ICU 16. The time of discharge was chosen to compare the error rates in this phase with the other moments of hospitalization. In case of death or transfer of the newborn to another unit, only the prescribed drugs of the period in which the newborn remained in the unit were considered.

The following data referring to neonates were collected: date of birth and hospitalization, GA, postmenstrual or corrected age, chronological age, gender, weight at admission, weight on each day of prescription and severity score (SNAPPE II - Score for Neonatal Acute Physiology, Perinatal Extension, Version II) 17. Regarding the prescribed drugs, the variables dose, interval, route of administration, diluents, and infusion rate, were collected. Formulations for parenteral nutrition, serotherapy, electrolytes, oxygen administration, blood products, vaccines, vitamins, contrasts, and topical products, were excluded from the analysis.

The term medication item was used for each item of prescribed drug.

All data were collected and analyzed by a pharmacist belonging to the team of researchers.

\section{Medication errors and prescribing errors}

Medication errors include prescribing errors, dispensing errors, medication administration errors, and patient compliance errors 18. For this study, the prescribing error was defined as an error that occurs at the stage of prescribing. Errors during dispensing or administering medication and the correct relationship and drug therapy were not evaluated.

All variables related to the prescribed drugs were compared with the Neofax database, which is used as a reference for prescription in the unit 19. As five variables were evaluated for each prescribed drug, the total number of errors could exceed the total number of prescribed drugs. The dose was considered incorrect and therefore classified as prescribing errors when presented a deviation of $\pm 10 \%$ of the recommended dose 9,20 . A margin of $\pm 10 \%$ of the lower and upper limit was used for medicines whose rates are indicated by ranges. The variation of newborn daily weight listed in their files was used to calculate the dose. The other variables (interval, route of administration, diluent and infusion rate) were classified as prescribing errors when they were not in accordance with the specifications of the baseline data used for analysis. The variables diluent and infusion rate were assessed only when necessary, such as for intravenous drugs, for example.

When the variables were necessary according to the Neofax, but they were not prescribed, they were classified as missing variables. No lack of variable was considered a prescribing error. Drugs were classified according to the Anatomical Therapeutic Chemical (ATC) classification of the World Health Organization 21.

\section{Statistical analysis}

The data was analyzed using SPSS 17.0 (SPSS Inc., Chicago, USA). Comparisons between groups of preterm and term infants were performed by using the Student t-test or Mann-Whitney test. To evaluate the relationship between qualitative variables we used the chi-square $\left(\chi^{2}\right)$ test. When the expected frequencies were less than five, Fisher's exact test was used to determine significance. To assess the types of medication errors in relation to the GA, logistic regression was used for obtaining the odds ratio (OR) at a $95 \%$ confidence interval $(95 \% \mathrm{CI})$. To verify the correlation between the number of errors and the characteristics of the newborn, the Spearman correlation analysis was done. Absolute and relative frequencies of errors were calculated. The significance level considered in all statistical analysis was $5 \%$.

\section{Results}

During the collection period, 224 neonates were admitted to the neonatal ICU. Of these, 151 met the inclusion criteria. One patient was excluded because he had only a single prescribed drug which was not included in the base used for analysis. Thus, 150 patients remained, most were male ( $n=90)$. Two patients had two admissions and one patient had three admissions to the unit. 25 deaths occurred during the study period. Table 1 describes the characteristics of the newborns and their prescriptions.

Data of 489 prescription order forms were collected. 11 prescription order forms were excluded because they contained only medication items that were not included in the database used. The remaining prescription order forms ( $n=478$ ) contained 1,616 items of medications; however 125 items were excluded because they do not appear in the Neofax database. The analyzed medication items $(n=1,491)$ represented 46 different drugs. The intravenous route was the most prescribed $(n=1,326)$, followed by oral $(n=$ 149) and subcutaneous $(n=1)$. Variables evaluated and prescribed totaled 5,522. There were 1,643 
General characteristics of the study population and drug prescriptions *. Neonatal intensive care unit, Minas Gerais, Brazil, between January and September 2011.

\begin{tabular}{|c|c|c|c|c|}
\hline & Preterm infants & Term infants & Total & p-value ** \\
\hline Number of patients (\%) & $106(70.7)$ & $44(29.3)$ & $150(100.0)$ & \\
\hline Gestational age (weeks) & $31.7 \pm 3.1$ & $38.7 \pm 1.2$ & $33.8 \pm 4.2$ & \\
\hline Weight at admission (g) & $1,510.8 \pm 599.6$ & $3,129.9 \pm 803.9$ & $1,800(1,136-2,641)$ & \\
\hline SNAPPE-II & $20.5(5.8-42.0)$ & $12.5(3.8-20.8)$ & $16(5-36)$ & \\
\hline Length of hospital stay (days) & $13.5(6.0-26.0)$ & $12.5(4.0-20.5)$ & $12.5(6-25)$ & 0.3815 \\
\hline Prescriptions order form/patient & $3(3-4)$ & $4(3-4)$ & $3.5(3-4)$ & 0.4777 \\
\hline Medication items/patient & $8(6-12)$ & $9.5(5.8-13.5)$ & $8.5(6-13)$ & 0.3040 \\
\hline Medication items/prescription order form & $2.7(2.0-3.6)$ & $3(2.0-4.3)$ & $2.8(2-4)$ & 0.4280 \\
\hline
\end{tabular}

* Normally distributed data, expressed as mean \pm standard deviation. Non-normally distributed data, expressed as median (25-75 quartiles);

** Mann-whitney test.

missing variable relating to route of administration $(n=15)$, interval $(n=75)$, diluents $(n=718)$ and infusion rate $(\mathrm{n}=835)$.

Among the prescribed drugs $(n=1,491), 648$ errors were found, corresponding to a rate of $43.5 \%$ prescribing errors. The percentage of prescribed drugs with one or more errors was $36.7 \%$ $(547 / 1,491)$. There was no significant difference in the number of errors between the first three moments of hospitalization, but the occurrence of errors was significantly lower $(p<0.0001)$ at the time of hospital discharge compared to the first three moments of hospitalization. Most errors involved medication items prescribed for intravenous $(94.8 \%)$ and oral $(5.2 \%)$ routes of administration.

The number of errors was significantly higher in preterm infants ( $\mathrm{p}=0.012, \chi^{2}$ test). The frequencies of errors per prescribed variable according to gestational age are shown in Table 2. Considering the total of analyzed variables, the chance of occurrence of errors was significantly higher in preterm infants compared to term infants. The most frequent errors were diluent, dose, and interval, regardless of gestational age.

Regarding the correlation of the clinical characteristics of newborns (weight at admission, GA and SNAPPE-II) with the number of errors, the results were significant only in the group of preterm infants. There were moderate negative correlations between number of errors and the weight at admission ( $r s=-0.4849$, $p<0.0001$ ) and $\mathrm{GA}$ ( $\mathrm{rs}=-0.3187, \mathrm{p}<0.0009$ ). A weak positive correlation ( $\mathrm{rs}=0.2982, \mathrm{p}<0.0019$ ) was observed with SNAPPE-II.

Considering the total number of errors, the classes of medication with the highest number of errors were anti-infectives for systemic use ( $\mathrm{n}=$ 296) and drugs for nervous $(\mathrm{n}=139)$ and cardiovascular $(\mathrm{n}=96)$ systems (Table 3$)$.

In relation to the class of anti-infective agents, ampicillin and gentamicin were the most prescribed and also more involved in prescribing errors in this study, and the majority of them occurred in preterm infants (Table 4). Of drugs that act on the nervous system, fentanyl $(n=76)$, morphine $(\mathrm{n}=30)$ and phenobarbital $(\mathrm{n}=22)$ were the most involved in errors. Regarding the cardiovascular system, furosemide $(n=44)$ and milrinone $(n=6)$ were respectively the diuretic and the inotropic more involved in prescribing errors. The frequency of errors by prescribed drug variable, according to gestational age and Anatomical Therapeutic Chemical Classification, is shown in Table 4.

\section{Discussion}

In accordance with the findings of several authors $1,3,7,8,11,13,22$, this study also shows that medication errors are common in a Brazilian neonatal ICU. Although most of these errors do not cause damage and are preventable within the neonatal unit $3,7,8,20$, some of them can cause severe injury and even death 13,23. Studies of medication errors are extremely important because they help to identify the most vulnerable stages of the process 11 and may contribute to the development of actions to promote their reduction. However, comparisons between the results of the studies are not always possible due to the use of different definitions of medication errors and different methods of analysis 11,24,25,26. 
Table 2

Frequencies of errors by prescribed variable according to gestational age. Neonatal intensive care unit, Minas Gerais, Brazil, between January and September 2011.

\begin{tabular}{|c|c|c|c|c|c|c|}
\hline \multirow[t]{2}{*}{ Variables } & \multicolumn{2}{|c|}{ Preterm infants } & \multicolumn{2}{|c|}{ Term infants } & \multirow{2}{*}{$\begin{array}{c}\text { OR } \\
(95 \% \mathrm{Cl})\end{array}$} & \multirow[t]{2}{*}{ p-value } \\
\hline & $n$ * & $\begin{array}{c}\text { Errors } \\
\text { n (\%) ** }\end{array}$ & $n$ * & $\begin{array}{c}\text { Errors } \\
\text { n (\%) ** }\end{array}$ & & \\
\hline Doses & 997 & $185(18.5)$ & 494 & $64(12.9)$ & $1.550(1.140-2.108)$ & $0.005 * \star \star$ \\
\hline Administration route & 987 & $0(0.0)$ & 489 & $0(0.0)$ & - & - \\
\hline Interval & 960 & $49(5.1)$ & 456 & $39(8.6)$ & $0.575(0.372-0.890)$ & $0.013 * \star \star$ \\
\hline Diluent & 415 & $212(51.0)$ & 226 & 79 (34.9) & $1.943(1.391-2.715)$ & $0.000 * \star \star$ \\
\hline Infusion rate & 324 & $15(4.6)$ & 174 & $5(2.9)$ & $1.641(0.586-4.593)$ & 0.346 \\
\hline Total & 3,683 & $461(12.5)$ & 1839 & 187 (10.2) & $1.264(1.056-1.513)$ & 0.011 *** \\
\hline
\end{tabular}

* $\mathrm{n}$ : total number of prescribed variables;

** $\mathrm{n}(\%)$ : absolute frequency (relative frequency) of the errors;

*** $\mathrm{p}$-value $<0.05$ indicating statistically significant differences among gestational ages (logistic regression).

95\% Cl: 95\% confidence interval.

Table 3

Frequency of errors of the prescribed drugs according to the Anatomical Therapeutic Chemical (ATC) classification and gestational age. Neonatal intensive care unit, Minas Gerais, Brazil, between Jan and Sept 2011.

\begin{tabular}{|c|c|c|c|c|c|c|c|}
\hline \multirow[t]{2}{*}{ ATC } & \multicolumn{2}{|c|}{ Preterms infants } & \multicolumn{2}{|c|}{ Terms infants } & \multirow{2}{*}{$\begin{array}{l}\text { Total } \\
\text { errors } \\
\text { n (\%) }\end{array}$} & \multirow[t]{2}{*}{ OR (IC95\%) } & \multirow[t]{2}{*}{ p-value } \\
\hline & $\begin{array}{l}\text { Drugs } \\
n *\end{array}$ & $\begin{array}{l}\text { Errors } \\
\text { n (\%) } \star \star\end{array}$ & $\begin{array}{c}\text { Drugs } \\
n *\end{array}$ & $\begin{array}{l}\text { Errors } \\
\text { n (\%) ** }\end{array}$ & & & \\
\hline Anti-infectives for systemic use & 434 & $246(56.7)$ & 147 & $50(34)$ & $296(45.7)$ & $2.54(1.71-3.75)$ & $\begin{array}{l}<0.0001 \\
\star \star \star\end{array}$ \\
\hline Nervous system & 179 & $80(44.7)$ & 151 & $59(39.1)$ & 139 (21.5) & $1.26(0.81-1.96)$ & 0.3585 \\
\hline Cardiovascular system & 82 & $39(47.6)$ & 108 & $57(52.8)$ & $96(14.8)$ & $0.81(0.46-1.44)$ & 0.5715 \\
\hline Respiratory system & 200 & $71(35.5)$ & 12 & $4(33.3)$ & $75(11.6)$ & $1.70(0.50-5.84)$ & 1,0000 \\
\hline Alimentary tract and metabolism & 52 & $16(30.8)$ & 37 & $15(40.5)$ & $31(4.8)$ & $0.65(0.27-1.57)$ & 0.4667 \\
\hline Musculoskeletal system & 26 & $5(19.2)$ & 17 & $2(11.8)$ & $7(1.1)$ & $1.79(0.30-10.47)$ & 0.6845 \\
\hline Genitourinary system and sex hormone & 19 & $4(21.1)$ & 19 & $0(0)$ & $4(0.6)$ & - & - \\
\hline Various & 4 & $0(0)$ & 2 & $0(0)$ & $0(0)$ & - & - \\
\hline Blood and blood forming organs & 0 & - & 1 & $0(0)$ & $0(0)$ & - & - \\
\hline $\begin{array}{l}\text { Systemic hormonal preparations, } \\
\text { excluding sex hormones and insulins }\end{array}$ & 1 & $0(0)$ & 0 & - & $0(0)$ & - & - \\
\hline Total & 997 & $461(46.2)$ & 494 & $187(37.8)$ & $648(43.5)$ & $1.40(1.13-1.76)$ & $0.0025 * \star \star$ \\
\hline
\end{tabular}

* $\mathrm{n}$ : total amount of prescribed drugs by ATC category;

** $\mathrm{n}(\%)$ : absolute frequency (relative frequency) of the errors;

*** $p$-value $<0.05$ indicating statistically significant differences among gestational ages (logistic regression).

$95 \% \mathrm{Cl}$ : $95 \%$ confidence interval.

Many studies have called attention to the prescription phase, since most medication errors occur during this phase $1,7,8,9$. The rate of prescribing errors observed in this study $(43.5 \%)$ was higher than that found by Campino et al. 20 (20.7\%). However, these authors did not assess diluent and infusion rate errors, as we did in this study. Regarding the percentage of pre- 
Frequencies of errors by prescribed variable according to gestational age and Anatomical Therapeutic Chemical Classification. Neonatal intensive care unit, Minas Gerais, Brazil, between January and September 2011

\begin{tabular}{|c|c|c|c|c|c|c|c|c|c|}
\hline \multirow[t]{2}{*}{ Drugs (ev/or/sc) } & \multicolumn{2}{|c|}{ Dose } & \multicolumn{2}{|c|}{ Interval } & \multicolumn{2}{|c|}{ Diluent } & \multicolumn{2}{|c|}{ Infusion rate } & \multirow{2}{*}{$\begin{array}{c}\text { Total } \\
\text { Variable error } \\
n(E)\end{array}$} \\
\hline & $\begin{array}{c}\text { Preterm } \\
\text { n (E) }\end{array}$ & $\begin{array}{l}\text { Term } \\
\text { n (E) }\end{array}$ & $\begin{array}{c}\text { Preterm } \\
\text { n (E) }\end{array}$ & $\begin{array}{l}\text { Term } \\
\text { n (E) }\end{array}$ & $\begin{array}{c}\text { Preterm } \\
\text { n (E) }\end{array}$ & $\begin{array}{l}\text { Term } \\
\text { n (E) }\end{array}$ & $\begin{array}{c}\text { Preterm } \\
\text { n (E) }\end{array}$ & $\begin{array}{l}\text { Term } \\
\mathrm{n}(\mathrm{E})\end{array}$ & \\
\hline \multicolumn{10}{|c|}{ Anti-infectives for systemic use } \\
\hline Aciclovir (ev) & 0 & $1(0)$ & 0 & $1(0)$ & 0 & $1(0)$ & 0 & $1(0)$ & $4(0)$ \\
\hline Amikacin (ev) & $7(2)$ & $2(0)$ & $7(2)$ & $2(0)$ & $7(1)$ & $2(2)$ & $7(0)$ & $2(0)$ & $36(7)$ \\
\hline Ampicillin (ev) & $169(46)$ & $35(0)$ & $168(0)$ & $35(0)$ & $1(0)$ & 0 & $3(0)$ & 0 & $411(46)$ \\
\hline Cefazolin (ev) & 0 & $5(1)$ & 0 & $5(4)$ & 0 & 0 & 0 & 0 & $10(5)$ \\
\hline Cefepime (ev) & $1(0)$ & $1(0)$ & $1(0)$ & $1(0)$ & $1(0)$ & 0 & $1(0)$ & 0 & $6(0)$ \\
\hline Cefotaxime (ev) & $18(0)$ & $22(0)$ & $18(0)$ & $22(3)$ & $15(0)$ & $19(0)$ & $14(2)$ & $17(1)$ & $145(6)$ \\
\hline Erythromycin (or) & $3(3)$ & 0 & $3(0)$ & 0 & NA & NA & NA & NA & $6(3)$ \\
\hline Fluconazole (ev) & $2(0)$ & 0 & $2(0)$ & 0 & 0 & 0 & $2(0)$ & 0 & $6(0)$ \\
\hline Ganciclovir (ev) & 0 & $4(4)$ & 0 & $4(0)$ & 0 & $4(0)$ & 0 & $4(0)$ & $16(4)$ \\
\hline Gentamicin (ev) & $185(56)$ & $39(0)$ & $183(34)$ & $38(1)$ & $180(85)$ & $38(14)$ & $164(3)$ & $31(2)$ & 858 (195) \\
\hline Meropenem (ev) & $2(0)$ & $5(0)$ & $2(0)$ & $5(3)$ & $2(0)$ & $3(0)$ & $2(0)$ & $5(0)$ & $26(3)$ \\
\hline Metronidazole (ev) & $1(0)$ & $6(1)$ & $1(0)$ & $6(1)$ & 0 & $4(4)$ & 0 & 0 & $18(6)$ \\
\hline Oxacillin (ev) & $15(1)$ & $21(7)$ & $15(0)$ & $21(1)$ & $1(0)$ & $4(0)$ & $4(0)$ & $1(0)$ & $82(9)$ \\
\hline Penicillin (ev) & $10(2)$ & $1(0)$ & $10(0)$ & $1(0)$ & $5(0)$ & $1(0)$ & $6(2)$ & $1(0)$ & $35(4)$ \\
\hline Vancomycin (ev) & $13(0)$ & $5(1)$ & $13(0)$ & $5(0)$ & $12(0)$ & $5(0)$ & $11(2)$ & $5(0)$ & $69(3)$ \\
\hline Zidovudine (ev/or) & $8(1)$ & 0 & $8(0)$ & 0 & $7(4)$ & 0 & $6(0)$ & 0 & $29(5)$ \\
\hline Total & $434(111)$ & $147(14)$ & $431(36)$ & $146(13)$ & $231(90)$ & $81(20)$ & $220(9)$ & $67(3)$ & $1,757(296)$ \\
\hline \multicolumn{10}{|l|}{ Nervous system } \\
\hline Caffeine (or) & $16(1)$ & $5(4)$ & $16(0)$ & $5(0)$ & NA & NA & NA & NA & $42(5)$ \\
\hline Phenobarbital (ev/or) & $21(3)$ & $42(15)$ & $20(0)$ & $41(0)$ & $4(3)$ & $1(0)$ & $7(0)$ & $4(1)$ & $140(22)$ \\
\hline Fentanyl (ev) & $115(1)$ & $52(0)$ & $109(0)$ & $49(0)$ & $67(59)$ & $27(6)$ & $24(0)$ & $17(0)$ & $460(76)$ \\
\hline Chloral hydrate (or) & $1(0)$ & $3(1)$ & $1(0)$ & $3(0)$ & NA & NA & NA & NA & $8(1)$ \\
\hline Midazolam (ev) & $10(3)$ & $10(2)$ & $9(0)$ & $10(0)$ & $4(0)$ & $6(0)$ & 0 & $2(0)$ & $51(5)$ \\
\hline Morphine (ev) & $16(0)$ & $39(2)$ & $15(0)$ & $37(0)$ & $10(10)$ & $18(18)$ & $4(0)$ & $10(0)$ & $149(30)$ \\
\hline Total & $179(8)$ & $151(24)$ & $170(0)$ & $145(0)$ & $85(72)$ & $52(34)$ & $35(0)$ & $33(1)$ & 850 (139) \\
\hline \multicolumn{10}{|l|}{ Cardiovascular system } \\
\hline Alprostadil (ev) & $3(0)$ & $16(0)$ & $2(0)$ & $7(0)$ & $3(0)$ & $16(7)$ & $3(0)$ & $16(0)$ & $66(7)$ \\
\hline Amiodarone (or) & $1(0)$ & $7(2)$ & $1(0)$ & $4(0)$ & 0 & $7(1)$ & 0 & $4(1)$ & $24(4)$ \\
\hline Captopril (or) & 0 & $2(1)$ & 0 & $2(0)$ & 0 & $2(0)$ & NA & NA & $6(1)$ \\
\hline Digoxin (or) & 0 & $5(0)$ & 0 & $5(0)$ & 0 & 0 & NA & NA & $10(0)$ \\
\hline Dobutamine (ev) & $28(0)$ & $25(0)$ & $21(0)$ & $14(0)$ & $28(11)$ & $25(7)$ & $27(0)$ & $25(0)$ & $193(18)$ \\
\hline Dopamine (ev) & $16(0)$ & $16(0)$ & $10(0)$ & $13(0)$ & $15(4)$ & $16(2)$ & $15(0)$ & $16(0)$ & $117(6)$ \\
\hline Epinephrine (ev) & $10(1)$ & $5(1)$ & $9(0)$ & $4(0)$ & $6(2)$ & $4(0)$ & $4(0)$ & $4(0)$ & $46(4)$ \\
\hline Furosemide (ev/or) & $10(6)$ & $20(7)$ & $9(8)$ & $20(19)$ & $1(1)$ & $3(3)$ & 0 & 0 & $63(44)$ \\
\hline Hydrochlorothiazide (or) & $3(0)$ & 0 & $3(0)$ & 0 & $3(3)$ & 0 & NA & NA & $9(3)$ \\
\hline Hydrocortisone (ev) & $1(0)$ & 0 & $1(0)$ & 0 & 0 & 0 & 0 & 0 & $2(0)$ \\
\hline Milrinone (ev) & $3(3)$ & $5(3)$ & $3(0)$ & $5(0)$ & $3(0)$ & $5(0)$ & $3(0)$ & $5(0)$ & $32(6)$ \\
\hline Propranolol (or) & 0 & $1(0)$ & 0 & $1(1)$ & 0 & $1(1)$ & NA & NA & $3(2)$ \\
\hline Spironolactone (or) & $7(0)$ & $6(0)$ & $7(0)$ & $5(1)$ & $7(0)$ & $6(0)$ & NA & NA & $38(1)$ \\
\hline Total & $82(10)$ & $108(14)$ & $66(8)$ & $80(21)$ & $66(21)$ & $85(21)$ & $52(0)$ & $70(1)$ & $609(96)$ \\
\hline \multicolumn{10}{|l|}{ Respioratory system } \\
\hline Aminophylline (ev/or) & $200(41)$ & $12(2)$ & $199(1)$ & $12(0)$ & $23(23)$ & $2(2)$ & $12(6)$ & $1(0)$ & $461(75)$ \\
\hline Total & $200(41)$ & $12(2)$ & $199(1)$ & $12(0)$ & $23(23)$ & $2(2)$ & $12(6)$ & $1(0)$ & $461(75)$ \\
\hline
\end{tabular}

(continues) 


\begin{tabular}{|c|c|c|c|c|c|c|c|c|c|}
\hline \multirow[t]{2}{*}{ Drugs (ev/or/sc) } & \multicolumn{2}{|c|}{ Dose } & \multicolumn{2}{|c|}{ Interval } & \multicolumn{2}{|c|}{ Diluent } & \multicolumn{2}{|c|}{ Infusion rate } & \multirow{2}{*}{$\begin{array}{c}\text { Total } \\
\text { Variable error } \\
n(E)\end{array}$} \\
\hline & $\begin{array}{c}\text { Preterm } \\
n(E)\end{array}$ & $\begin{array}{l}\text { Term } \\
\mathrm{n}(\mathrm{E})\end{array}$ & $\begin{array}{l}\text { Preterm } \\
n(E)\end{array}$ & $\begin{array}{l}\text { Term } \\
\mathrm{n}(\mathrm{E})\end{array}$ & $\begin{array}{l}\text { Preterm } \\
\mathrm{n}(\mathrm{E})\end{array}$ & $\begin{array}{l}\text { Term } \\
n(E)\end{array}$ & $\begin{array}{l}\text { Preterm } \\
n(E)\end{array}$ & $\begin{array}{l}\text { Term } \\
\mathrm{n}(\mathrm{E})\end{array}$ & \\
\hline \multicolumn{10}{|l|}{$\begin{array}{l}\text { Alimentary tract and } \\
\text { metabolism }\end{array}$} \\
\hline Atropine (ev) & $18(1)$ & $4(0)$ & $14(0)$ & $3(0)$ & $1(1)$ & 0 & $2(0)$ & 0 & $42(2)$ \\
\hline Insulin (ev) & $1(1)$ & 0 & 0 & 0 & $1(0)$ & 0 & NA & NA & $2(1)$ \\
\hline Omeprazole (or) & 0 & $5(0)$ & 0 & $5(0)$ & NA & NA & NA & NA & $10(0)$ \\
\hline Ranitidine (ev/or) & $33(9)$ & $28(10)$ & $33(4)$ & $28(5)$ & $2(0)$ & $4(0)$ & $1(0)$ & $2(0)$ & $131(28)$ \\
\hline Total & $52(11)$ & $37(10)$ & $47(4)$ & $36(5)$ & $4(1)$ & $4(0)$ & $3(0)$ & $2(0)$ & $185(31)$ \\
\hline \multicolumn{10}{|l|}{ Musculosketal system } \\
\hline Vecuronium (ev) & $20(0)$ & $4(0)$ & $17(0)$ & $3(0)$ & $1(1)$ & 0 & 0 & 0 & $45(1)$ \\
\hline Pancuronium (ev) & $6(0)$ & $13(0)$ & $6(0)$ & $13(0)$ & $4(4)$ & $2(2)$ & $2(0)$ & $1(0)$ & $47(6)$ \\
\hline Total & $26(0)$ & $17(0)$ & $23(0)$ & $16(0)$ & $5(5)$ & $2(2)$ & $2(0)$ & $1(0)$ & $92(7)$ \\
\hline \multicolumn{10}{|c|}{$\begin{array}{l}\text { Genitourinary system and } \\
\text { sex hormone }\end{array}$} \\
\hline Sildenafil (or) & $19(4)$ & $19(0)$ & $19(0)$ & $19(0)$ & NA & NA & NA & NA & $76(4)$ \\
\hline Total & $19(4)$ & $19(0)$ & $19(0)$ & $19(0)$ & NA & NA & NA & NA & $76(4)$ \\
\hline \multicolumn{10}{|l|}{ Various } \\
\hline Naloxone (ev) & $4(0)$ & $2(0)$ & $4(0)$ & $1(0)$ & NA & NA & NA & NA & $11(0)$ \\
\hline Total & $4(0)$ & $2(0)$ & $4(0)$ & $1(0)$ & NA & NA & NA & NA & $11(0)$ \\
\hline \multicolumn{10}{|c|}{$\begin{array}{l}\text { Blood and blood forming } \\
\text { organs }\end{array}$} \\
\hline Enoxaparin (sc) & 0 & $1(0)$ & 0 & $1(0)$ & NA & NA & NA & NA & $2(0)$ \\
\hline Total & 0 & $1(0)$ & 0 & $1(0)$ & NA & NA & NA & NA & $2(0)$ \\
\hline \multicolumn{10}{|l|}{ Systemic hormonal } \\
\hline \multicolumn{10}{|c|}{ preparations, excluding sex } \\
\hline \multicolumn{10}{|l|}{ hormones and insulins } \\
\hline Levothyroxine (or) & $1(0)$ & 0 & $1(0)$ & 0 & $1(0)$ & 0 & NA & NA & $3(0)$ \\
\hline Total & $1(0)$ & 0 & $1(0)$ & 0 & $1(0)$ & 0 & NA & NA & $3(0)$ \\
\hline
\end{tabular}

E: absolute frequency of errors; $n$ : total number of prescribed variables; ev: intravenous; NA: not applicable to the prescribed drug; or: oral; sc: subcutaneous.

scribed items that had at least one error, the rate de $36.7 \%$ reported in the present study is within the variation range reported by Campino et al. 20 (19.2\%), Pallas et al. ${ }^{9}$ (39.5\%) and Deshpande 27 (52\%). Even higher rates $(78.1 \%)$ were reported by Alagha et al. 28 in a study conducted in a pediatric ICU. As referenced by other authors 1,8 , in this study the majority of errors (94.8\%) were related to prescribed drugs for intravenous use. Within this context, it is important to note that the drug dispensing system by unit dose presents many advantages, among which the reduction of medication errors stands out 29 .

The stratification by GA of the patients hospitalized in the neonatal ICU considered in this study showed that preterm infants experienced more prescribing errors and that prematurity is a risk factor for the occurrence of this type of error, either by prescribed variable $(\mathrm{OR}=1.264$, Table 2$)$, or by prescribed drug $(\mathrm{OR}=1.4$, Table 3$)$.
Special attention should be given to this finding since the critically ill and younger newborns are less able to mitigate such errors 1 . Other authors $16,30,31$ have also shown that preterm infants and those in need of complex medical care had higher rates of errors.

Among the errors found in this study, the diluent stood out because it accounted for $44.9 \%$ of the total. Serra et al. 32 recorded no diluent error, but only errors of dose and interval in a neonatal ICU. The evaluation of the prescribed diluent is often not included in the analysis of prescription and usually reported in studies on errors in the administration phase 3,33 . Therefore evaluating this type of error is very important, since the use of an inappropriate diluent can lead to a reduced stability and activity of the drug, and possible precipitation ${ }^{33}$.

Dose and interval errors have also been reported as common prescribing errors 1,7,8,9,13,20,32. 
Chedoe et al. 11, in a systematic review of the literature on medication errors in neonatal ICUs, reported that the dose error is the most frequent type of error. However, in this study the incorrect dose was the second most frequent type of error. This is justified, in part, because the prescribed diluent has been evaluated in this study. Nevertheless, errors in dose and interval found here, $38.4 \%$ and $13.6 \%$ respectively, are close to the values of $35.2 \%$ and $18.1 \%$ reported by Simpson et al. ${ }^{8}$. Kaushal et al. 1, in a study of medication errors in pediatrics found that among the potential adverse events, ie, errors that could cause harm to patients, the most common were dose, interval and route of administration. The present study showed that there was a negative correlation between the weight of the newborn at admission in the neonatal ICU and the number of medication errors for the preterm infants, and also a greater chance $(\mathrm{OR}=1.55)$ of dosing errors compared with term infants. The study by Kanter et al. 34 also reported an inverse linear relationship between birth weight and the rate of errors. As important as the dose, the interval between them should also be monitored carefully, since it is necessary to adjust the dose to the age of the newborn to medications such as antimicrobials 35 . The frequency of errors in dose and interval in a neonatal ICU can be associated with the use of weight, body surface, and gestational and chronological ages in the calculations of the dose and interval 2,6. Therefore, prescribers should be aware of these variables, otherwise inadequate doses may be prescribed 35. Furthermore, another peculiarity of neonatal pharmacotherapy is the frequent prescription of off-label or unlicensed medicines, ie those that are not approved for this age group, and are therefore a great challenge to neonatologists 2,36.

Error in the infusion rate was also found in the present study, althought in a smaller proportion $(3.1 \%)$. Other authors have reported higher rates for this type of error, but the data from these studies were obtained in the evaluation of the preparation and administration of medications 16,24,32,37.

Although in this study, the omission of variables (route of administration, interval, diluent and infusion rate) was not considered a prescribing error, these findings lead to reflection, and may be subject to intervention, since the omission can lead to error. Cousins et al. 33 suggest that one of the causes of errors in the infusion rate and diluent for drugs administered intravenously, may be associated with the fact that these variables are not often specified in the prescription, being at the discretion of the healthcare worker who will administer the medication to es- tablish the diluent and infusion rate. In a recent protocol published by Ministry of Health of Brazil 38 it is recommended that these variables must be properly specified in the prescription.

In concordance with the data reported by other authors $1,3,9,22,24$, the results of this study also showed that the class of anti-infective for systemic use and drugs for cardiovascular and nervous systems are more involved in errors. This is probably due to the frequent use of these drugs in the neonatal ICU, since the risk of occurrence of error is directly proportional to the frequency of use 22 . This may also explain why the number of errors at the time of discharge from the neonatal ICU was lower when compared with the other moments, since the number of medication items prescribed was lower at discharge from the neonatal ICU. Regarding anti-infective agents, Simpson et al. 8 also reported gentamicin as the parenteral drug most involved in errors. Ampicillin and gentamicin are drugs that are often prescribed in the neonatal ICU, as part of empirical antibiotic therapy 36,39 . Serious adverse effects of nephrotoxicity and ototoxicity are well known in response to aminoglycosides ${ }^{3}$ and therefore, attention should be given when prescribing these drugs.

Fentanyl, morphine and phenobarbital were also frequently involved in errors, which is consistent with reports by other authors 3,8. Errors involving morphine sulfate are potentially lethal in children 24. Differently from what happened in the classes of anti-infectives and drugs that act on the nervous system, most errors for drugs acting on the cardiovascular system occurred in term infants, and the drug with the highest number of errors was furosemide. It is noteworthy for this class of medicines that milrinone, along with other drugs mentioned in this study (fentanyl, morphine, midazolam, chloral hydrate, insulin and amiodarone) are on the list of high-alert medications, which have an increased risk of causing harm to the patient if not used properly 40 .

The results of this study reinforce the need for studies on medication errors in the neonatal ICU, since these errors are common. The safety of the newborn should be the goal of the entire care team and measures should be evaluated and implemented in order to prevent the occurrence of medication errors. Measures such as computerized physician order entry, presence of clinical pharmacist on the unit and improved communication between pharmacists, nurses and doctors, have been shown to be effective in reducing errors 7 .

Limitations of this study include the following: its retrospective design, which prevents the 
researchers from contacting the prescriber to find out whether there was any clinical situation justifying this gap; the definition of dose error as $10 \%$ dose errors deviation from the recommended dose; the number of drugs excluded from the analysis because Neofax does not include them; the lack of evaluation of the impact of the errors found; the lack of evaluation of the prescribed electrolytes; the failure to consider as a prescribing error the lack of a necessary variable in the prescription; and its limitation to a single hospital. Despite the limitations of this study the findings of this study may contribute to the implementation of necessary actions for improvement in newborn care.

\section{Resumen}

Pacientes pediátricos, principalmente internados en unidades de terapia intensiva (UTI) neonatal, son altamente vulnerables a los errores de medicación. El objetivo de este estudio fue conocer la frecuencia de los errores de prescripción en una UTI neonatal de un hospital universitario así como, los pacientes susceptibles, los tipos de errores y los medicamentos involucrados. Las variables prescritas relacionadas a los medicamentos fueron comparadas con la base utilizada como referencia para la prescripción en la unidad (Neofax). Participaron en el estudio 150 recién nacidos. Se analizaron 489 prescripciones, 1.491 ítems de medicamentos, correspondiendo a 46 fármacos. La tasa de errores de prescripción fue de un 43,5\%. Fueron encontrados errores de dosis, intervalo, diluyente y tiempo de infusión, distribuidos en 7 clases terapéuticas. La ocurrencia de errores fue mayor en recién nacidos prematuros. Los errores de diluyente y de dosis fueron los más frecuentes. Las clases de medicamentos más involucrados en los errores fueron los anti-infecciosos y aquellos que actúan en el sistema nervioso y cardiovascular.

Prescripción Inadecuada; Prematuro; Recién Nacido; Unidades de Cuidado Intensivo Neonatal

\section{Conclusion}

Medication errors were common, especially in preterm infants. The most frequent types of errors were diluent, dose and interval. The drug classes most involved were anti-infective agents and drugs that act on the nervous and cardiovascular systems. The data from this study may help to raise the awareness of health professionals about the need to establish measures for reducing medication errors in evaluated neonatal intensive care units.

\section{Contributors}

All the authors contributed equally to the study's planning, development, analysis, and technical draft.

\section{Acknowledgments}

This work was supported by CNPq. 


\section{References}

1. Kaushal R, Bates DW, Landrigan C, McKenna KJ Clapp MD, Federico F, et al. Medication errors and adverse drug events in pediatric inpatients. JAMA 2001; 285:2114-20.

2. Gray JE, Goldmann DA. Medication errors in the neonatal intensive care unit: special patients, unique issues. Arch Dis Child Fetal Neonatal Ed 2004; 89:F472-3.

3. Stavroudis TA, Shore AD, Morlock L, Hicks RW, Bundy D, Miller MR. NICU medication errors: identifying a risk profile for medication errors in the neonatal intensive care unit. J Perinatol 2010; 30:459-68.

4. Neubert A, Lukas K, Leis T, Dormann H, Brune K, Rascher W. Drug utilisation on a preterm and neonatal intensive care unit in Germany: a prospective, cohort-based analysis. Eur J Clin Pharmacol 2010; 66:87-95.

5. Frattarelli DA, Galinkin JL, Green TP, Johnson TD, Neville KA, Paul IM, et al. American Academy of Pediatrics Committee on Drugs. Off-label use of drugs in children. Pediatrics 2014; 133:563-7

6. Lehmann CU, Kim GR. Prevention of medication errors. Clin Perinatol 2005; 32:107-23.

7. Fortescue EB, Kaushal R, Landrigan CP, McKenna KJ, Clapp MD, Federico F, et al. Prioritizing strategies for preventing medication errors and adverse drug events in pediatric inpatients. Pediatrics 2003; 111(4 Pt 1):722-9.

8. Simpson JH, Lynch R, Grant J, Alroomi L. Reducing medication errors in the neonatal intensive care unit. Arch Dis Child Fetal Neonatal Ed 2004; 89:F480-2.

9. Pallás CR, De-la-Cruz J, Del-Moral MT, Lora D, Malalana MA. Improving the quality of medical prescriptions in neonatal units. Neonatology 2008; 93:251-6.

10. Conroy S, Sweis D, Planner C, Yeung V, Collier J, Haines $\mathrm{L}$, et al. Interventions to reduce dosing errors in children: a systematic review of the literature. Drug Saf 2007; 30:1111-25.

11. Chedoe I, Molendijk HA, Dittrich ST, Jansman FG, Harting JW, Brouwers JR, et al. Incidence and nature of medication errors in neonatal intensive care with strategies to improve safety: a review of the current literature. Drug Saf 2007; 30:503-13.

12. Simons SL. Designing medication safety in the NICU. Neonatal Netw 2007; 26:407-8.

13. Otero P, Leyton A, Mariani G, Ceriani Cernadas JM; Patient Safety Committee. Medication errors in pediatric inpatients: prevalence and results of a prevention program. Pediatrics 2008; 122:e737-43.

14. Reason J. Human error: models and management. BMJ 2000; 320:768-70.

15. WHO: recommended definitions, terminology and format for statistical tables related to the perinatal period and use of a new certificate for cause of perinatal deaths. Modifications recommended by FIGO as amended October 14, 1976. Acta Obstet Gynecol Scand 1977; 56:247-53.

16. Lerner RB, Carvalho MD, Vieira AA, Lopes JM, Moreira ME. Medication errors in a neonatal intensive care unit. J Pediatr (Rio J.) 2008; 84:166-70.
17. Richardson DK, Corcoran JD, Escobar GJ, Lee SK. SNAP-II and SNAPPE-II: simplified newborn illness severity and mortality risk scores. J Pediatr 2001; 138:92-100.

18. ASHP guidelines on preventing medication errors in hospitals. Am J Hosp Pharm 1993; 50:305-14.

19. Young TE, Magnum B. Neofax. 21st Ed.New York: Thomson Reuteurs; 2010.

20. Campino A, Lopez-Herrera MC, Lopez-de-Heredia I, Valls-i-Soler A. Educational strategy to reduce medication errors in a neonatal intensive care unit. Acta Paediatr 2009; 98:782-5.

21. World Health Organization. Collaborating Centre for Drug Statistics Methodology. ATC/DDD. http:// www.whocc.no/atc_ddd_index/ (accessed on 23/ $\mathrm{Jul} / 2013)$.

22. Stavroudis TA, Miller MR, Lehmann CU. Medication errors in neonates. Clin Perinatol 2008; 35:141-61.

23. Levine S, Cohen M, Blanchard N, Frederico F, Magelli M, Lomax C, et al. Guidelines for preventing medication errors in pediatrics. J Pediatr PharmacolTher 2001; 6:426-42.

24. Ross LM, Wallace J, Paton JY. Medication errors in a paediatric teaching hospital in the UK: five years operational experience. Arch Dis Child 2000; 83:492-7.

25. Davis T. Paediatric prescribing errors. Arch Dis Child 2011; 96:489-91.

26. Alsulami Z, Conroy S, Choonara I. Medication errors in the Middle East countries: a systematic review of the literature. Eur J Clin Pharmacol 2013; 69:995-1008.

27. Deshpande SA. How common are violations of good prescribing practice in the neonatal unit. Arch Dis Child 2003; 88 Suppl 1:A20.

28. Alagha HZ, Badary OA, Ibrahim HM, Sabri NA. Reducing prescribing errors in the paediatric intensive care unit: an experience from Egypt. Acta Paediatr 2011; 100:e169-74.

29. Anacleto TA, Perini E, Rosa MB, César CC. Medication errors and drug-dispensing systems in a hospital pharmacy. Clinics (São Paulo) 2005; 60:32532.

30. Vincer MJ, Murray JM, Yuill A, Allen AC, Evans JR, Stinson DA. Drug errors and incidents in a neonatal intensive care unit. A quality assurance activity. Am J Dis Child 1989; 143:737-40.

31. Slonim AD, LaFleur BJ, Ahmed W, Joseph JG. Hospital-reported medical errors in children. Pediatrics 2003; 111:617-21.

32. Serra VV, Pena F, Ossorio MF, Pedicone C, Armadans M. Errores de prescripcion de drogas endovenosas en una unidad de cuidados neonatales de la ciudad de Buenos Aires. Rev Fac Cien Med Univ Nac Cordoba 2012; 69:15-9.

33. Cousins DH, Sabatier B, Begue D, Schmitt C, Hoppe-Tichy T. Medication errors in intravenous drug preparation and administration: a multicentre audit in the UK, Germany and France. Qual Saf Health Care 2005; 14:190-5.

34. Kanter DE, Turenne W, Slonim AD. Hospital-reported medical errors in premature neonates. Pediatr Crit Care Med 2004; 5:119-23. 
35. Cheng CL, Yang YH, Lin SJ, Lin CH, Lin YJ. Compliance with dosing recommendations from common references in prescribing antibiotics for preterm neonates. Pharmacoepidemiol Drug Saf 2010; 19:51-8.

36. Carvalho CG, Ribeiro MR, Bonilha MM, Fernandes Jr M, Procianoy RS, Silveira RC. Use of off-label and unlicensed drugs in the neonatal intensive care unit andits association with severity scores. J Pediatr (Rio J.) 2012; 88:465-70.

37. Raju TN, Kecskes S, Thornton JP, Perry M, Feldman S. Medication errors in neonatal and paediatric intensive-care units. Lancet 1989; 2:374-6.

38. Ministério da Saúde. Protocolo de segurança na prescrição, uso e administração de medicamentos. http://www.portalsaude.saude.gov.br/seguranca dopaciente (accessed on 26/Jan/2014).
39. Lass J, Käär R, Jõgi K, Varendi H, Metsvaht T, Lutsar I. Drug utilisation pattern and off-label use of medicines in Estonian neonatal units. Eur J Clin Pharmacol 2011; 67:1263-71.

40. Institute for Safe Medication Practices. ISMP list of high-alert medications in acute care settings. http://www.ismp.org/Tools/institutionalhighAlert. asp (accessed on 26/Jan/2014).

Submitted on 30/Dec/2014

Final version resubmitted on 18/Jun/2015

Approved on 01/Jul/2015 